\title{
Thinning decreased soil respiration differently in two dryland Mediterranean forests with contrasted soil temperature and humidity regimes
}

\author{
Inmaculada Bautista ${ }^{1} \cdot$ Antonio Lidón $^{1} \cdot$ Cristina Lull $^{1}$ - María González-Sanchis ${ }^{2} \cdot$ Antonio D. del Campo $^{2}$
}

Received: 16 March 2021 / Revised: 7 September 2021 / Accepted: 8 September 2021 / Published online: 22 September 2021

(c) The Author(s) 2021

\begin{abstract}
The effects of a thinning treatment on soil respiration (Rs) were analysed in two dryland forest types with a Mediterranean climate in east Spain: a dry subhumid holm oak forest (Quercus ilex subsp. ballota) in La Hunde; a semiarid postfire regenerated Aleppo pine (Pinus halepensis) forest in Sierra Calderona. Two twin plots were established at each site: one was thinned and the other was the control. Rs, soil humidity and temperature were measured regularly in the field at nine points per plot distributed into three blocks along the slope for 3 years at HU and for 2 years at CA after forest treatment. Soil heterotrophic activity was measured in laboratory on soil samples obtained bimonthly from December 2012 to June 2013 at the HU site. Seasonal Rs distribution gave low values in winter, began to increase in spring before lowering as soil dried in summer. This scenario indicates that with a semiarid climate, soil respiration is controlled by both soil humidity and soil temperature. Throughout the study period, the mean Rs value in the HU C plot was $13 \%$ higher than at HU T, and was $26 \%$ higher at CA $\mathrm{C}$ than the corresponding CA $\mathrm{T}$ plot value, being the differences significantly higher in control plots during active growing periods. Soil microclimatic variables explain the biggest proportion of variability for Rs: soil temperature explained $24.1 \%$ of total variability for Rs in the dry subhumid forest; soil humidity accounted for $24.6 \%$ of total variability for Rs in the semiarid forest. As Mediterranean climates are characterised by wide interannual variability, Rs showed considerable variability over the years, which can mask the effect caused by thinning treatment.
\end{abstract}

Keywords Soil climate $\cdot$ Soil hydrology $\cdot$ Forest management $\cdot$ Topography

\section{Introduction}

The world's forests store more than $80 \%$ of all terrestrial aboveground carbon, and more than $70 \%$ of all soil organic carbon (Dixon et al. 1994; Jandl et al. 2007). The carbon balance in an ecosystem is the net result of $\mathrm{CO}_{2}$ fixation

Communicated by Agustin Merino.

Inmaculada Bautista

ibautista@qim.upv.es

1 Research Group in Forest Science and Technology (Re-ForeST), Research Institute of Water and Environmental Engineering (IIAMA), Universitat Politècnica de València, Camí de Vera s/n, 46022 Valencia, Spain

2 Hydraulic Engineering and Environment Department, Research Group in Forest Science and Technology (Re-ForeST), Universitat Politècnica de València, Camí de Vera s/n, 46022 Valencia, Spain by photosynthesis occurring aboveground and the release of carbon as $\mathrm{CO}_{2}$ from both above and belowground compartments. In forest ecosystems, the $\mathrm{CO}_{2}$ flux from the soil surface, or soil respiration (Rs), accounts for $30-80 \%$ of total ecosystem respiration (Davidson et al. 2006). The belowground carbon outputs are balanced by organic carbon inputs to soil via litterfall and annual root turnover, and by root exudates (Ågren and Knecht 2001; Ukonmaanaho et al. 2008).

Rs is the sum of both soil autotrophic and heterotrophic respirations. Autotrophic respiration agents are roots and their associated mycorrhizae, whereas heterotrophic respiration is performed by saprophytic fungi and bacteria, and also by soil meso- and macrofauna. The former is maintained by the current assimilates produced by photosynthesis and root starch reserves at the beginning of the growing season (Högberg et al. 2001). The latter is maintained by the decomposition of organic debris on forest floors and stabilised organic matter on the ground. Estimates of root respiration contribution to total Rs range from 10-90\% 
(Hanson et al. 2000), and can seasonally vary between growing and non-growing periods (Högberg et al. 2001; Rey et al. 2003; Tang et al. 2005a).

Soil biological activity is controlled by environmental conditions, mainly temperature and water and substrate availability. In climate zones where biological activity is controlled by water availability, such as Mediterranean ecosystems, it is necessary to understand the effect of water on Rs. The effect of soil humidity is complex because Rs is restricted by lack of water, but also by excess water as the latter induces oxygen deficiency, especially during high oxygen demand periods (Curtin et al. 2012).

Current climate evolution models estimate a temperature rise of around $3-4^{\circ} \mathrm{C}$ in the Mediterranean Region in Europe, along with an expected drop in current annual precipitation of up to $20 \%$ (up to $50 \%$ less in summer) (Lindner et al. 2010). The Mediterranean Region is especially sensitive to climate change impacts given the high sensitivity of ecosystem productivity to water availability. Cabon et al. (2018) warns about the rising vulnerability of oak coppices in Southern Europe to drought as a result of ongoing climate change. In this area, one research priority is to study how human intervention can mediate the adaptation of forests to environmental changes (Scarascia-Mugnozza et al. 2000; Lindner et al. 2010; del Campo et al. 2017). To detect and predict future changes in the forest ecosystem function, the patterns, controls and variability of forest productivity within and among stands must be better understood (Newman et al. 2006). Awareness of the impact of forest management on forest resilience against environmental changes has grown (Jandl et al. 2019).

Forest thinning, which is the most frequent forest management practice, increases forest productivity, but also helps to enhance ecosystem resilience (Millar et al. 2007; del Campo et al. 2019), increase water availability (Molina and del Campo 2012) or improve tree growth and vigour (Olivar et al. 2014). In semiarid areas, the idea of using thinning as an adaptation strategy to climate change is emerging as a means to improve forests' resistance to climate change by decreasing water competition between the remaining stems. Several studies have analysed the effect of thinning on forest tolerance to drought (D'Amato et al. 2013; Cabon et al. 2018; del Campo et al. 2019). When implementing hydrology-oriented forest management, a shift in the paradigm of full canopy cover to medium covers occurs (40-50\%). A previous work (del Campo et al. 2018) has shown that a reduced forest biomass in a Mediterranean climate significantly increases net rainfall by reducing canopy interception. Net water gain accumulates mainly on the forest floor and is lost from the soil surface by evaporation, which leads to more dynamic water content changes on the soil surface layer (del Campo et al. 2019).
Studies that examine soil $\mathrm{CO}_{2}$ flux patterns and mechanisms in response to management practices are important as a means to enhance forest $C$ sequestration (Peng et al. 2008). The carbon sequestration potential in forest land through forest management practices is estimated at $0.94-2.45 \mathrm{Pg} \mathrm{C}$ year $^{-1}$ (Lal et al. 2018). Thinning practices can potentially influence soil respiration (autotrophic and heterotrophic respiration) by modifying root activity, labile organic $\mathrm{C}$ inputs, substrate availability, soil temperature and soil water content (Thibodeau et al. 2000; López et al. 2003; Xu et al. 2011; López-Serrano et al. 2016; Martínez-García et al. 2017).

Thinning strongly affects the forest carbon pools, since reduces the canopy structure and increases the amount of woody debris, which are normally scattered on the ground. The spatial pattern of litter has been largely influenced by the amount of downed woody debris and downed trees at sites (Martin and Timmer 2006). Notwithstanding, the effects of thinning on carbon fluxes are not so evident. Previous studies have reported contradictory effects of thinning on Rs. Toland and Zak (1994) found that daily rates of soil respiration did not significant differ between intact and clear-cut plots; Striegl and Wickland (1998) reported a great reduction in soil respiration in the growing season after clear-cut, whereas Ohashi et al. (1999) reported soil respiration rates in the thinned section significantly higher. In recent years, the number of studies into forest thinning impacts on Rs in the Mediterranean Region has increased also with contrasting conclusions. Some authors have reported significantly higher Rs with thinning for the first year after treatment (Akburak and Makineci 2016; López-Serrano et al. 2016). In contrast, Tang et al. (2005b) observed a 13\% reduction in total Rs after thinning. These authors suggested that this decrease could be associated with reduced root density. Other authors observed no effect of thinning on soil respiration (Campbell et al. 2009). Chang et al. (2016) indicated that Rs response to thinning was species-dependent with Rs responding less to thinning in deep-rooted species. The general review by Zhang et al. (2018) reported an initial increase in Rs after light or moderate thinning intensity in broadleaved or mixed forests. Afterwards, Rs gradually lowered to the original prethinning level.

Soil respiration is very responsive to climate conditions. Although a quasi-general agreement has been reached for modelling the soil temperature effect on microbial activity using exponential functions or $\mathrm{Q}_{10}$ functions (Lloyd and Taylor 1994; Pang et al. 2013), the effect of water availability on Rs does not show a similar pattern. Several types of relations have been proposed to model soil humidity effects on Rs (López-Serrano et al. 2016; Martínez-García et al. 2017). It has also been shown that the relation between Rs and soil humidity is affected by soil properties (Moyano et al. 2012). Apart from this complexity, wetting pulses after dry periods trigger a burst of microbial activity as a result 
of increased substrate availability after rewetting (Almagro et al. 2009; Lado-Monserrat et al. 2014).

A special characteristic of Mediterranean area is that forests concentrate mainly in mountain areas with high slopes (Yaalon 1997). Slope and aspect angles induce great heterogeneity in soil properties along slopes, and increase Rs spatial variability (Xu and Qi 2001; Ohashi and Gyokusen 2007). Topography strongly influences soil humidity by creating spatial patterns that influence Rs (Martin and Bolstad 2009). The analysis of the spatial variability + topography interaction on soil $\mathrm{CO}_{2}$ emissions is essential for scaling up processes measured on small scales (plot) to an ecosystem scale.

This study is framed within an overall project that aims to evaluate the effects of adaptive forest management on water fluxes, growth dynamics, field $\mathrm{CO} 2$ flux and soil properties. Selective thinning was studied in two dryland forest types with a Mediterranean climate in east Spain as an adaptive measure to compensate for rainfall reduction (del Campo et al. 2019). Both forests differ in aridity and present two distinct dominant species: Quercus ilex spp. ballota at La Hunde and Pinus halepensis at Sierra Calderona. At both study sites, two twin plots were established: one was thinned and the other acted as a control. The present study offers experimental data showing the effects of management intensity on soil respiration to better understand carbon-water coupling under forest treatments. Our hypothesis is that climatic conditions in the Mediterranean, especially water availability controls soil respiration. The high variability between years in water resources can control canopy cover evolution after thinning and the relative contribution of autotrophic and heterotrophic respiration and thus can mask a clear response of soil carbon fluxes to thinning. The aims of this study were to: (1) determine the influence of thinning on soil respiration and microclimate; (2) compare thinning effects on soil respiration among forests; (3) determine which factors affected soil respiration after thinning.

\section{Material and methods}

\section{Study sites}

This study was carried out in two different forested areas in east Spain with high tree density and fierce competition (del Campo et al. 2018). La Hunde (HU) site (3904'50", $\mathrm{N}, 1^{\circ} 14^{\prime} 47^{\prime \prime} \mathrm{W}$, at 1090 m.a.s.l) is located near Ayora, SW Valencia (Spain) at the headwaters of the Rambla Espadilla catchment. The Calderona site (CA) $\left(39^{\circ} 42^{\prime} 29^{\prime \prime} \mathrm{N}, 0^{\circ} 27^{\prime} 25^{\prime \prime}\right.$ $\mathrm{W}$, at 790 m.a.s.l.) is located in the Sierra Calderona Natural Park, a mountain range that separates the basins of the Palancia and Turia rivers. Both sites differ not only in vegetation, but also in climate, rainfall annual distribution and soil characteristics (del Campo et al. 2018). At HU, $150 \mathrm{~km}$ inland, climate is continental with average annual precipitation of $466 \mathrm{~mm}$ and mean annual temperature of $12.8^{\circ} \mathrm{C}$, whereas the CA site has marked influence from the Mediterranean Sea, which is $25 \mathrm{~km}$ away and has annual values of $342 \mathrm{~mm}$ and $14{ }^{\circ} \mathrm{C}$ for rainfall and mean temperature. Following the drylands classification according to the Aridity Index (UNEP, 1992), CA is defined as semiarid and presents drier conditions than $\mathrm{HU}$, which has a dry subhumid climate.

HU presents a coppice oak and shrubland forest, developed as a result of traditional fuelwood harvesting that fell into disuse in the 1970s. The dominant species there is Quercus ilex ssp. ballota, with some $Q$. faginea and Pinus halepensis trees. The understory shrubs are mainly Juniperus phoenicea and J. oxycedrus. Orientation is NW with a mean slope of 30\% (Fig. 1a). In May 2012, two contiguous experimental plots $\left(1,800 \mathrm{~m}^{2}\right.$ each) were established: one without treatment (HU C) and the one subjected to thinning with shrub clearing treatment (HU T), where tree density reduction was $73 \%$ and the removed basal area was $41 \%$. Trees were chosen in an attempt to achieve homogeneous spatial distribution in the whole plot. Timber was exported after treatment, but branches, twigs and leaves were cut down and ground into mulch in the thinned area. In summer 2013, some pines were ringed and later cut down in September 2013.

The CA plots were established in an Aleppo pine (Pinus halepensis Mill.) forest, which was regenerated after a wildfire in 1992. Spontaneous regeneration, together with lack of management, created highly dense pine saplings, with over 15,000 trees/ha (del Campo et al. 2018). A thinning treatment intervention was performed in the 8.3 ha of fired forest. Between January and October 2012, the overall area was thinned by cutting $94 \%$ of trees except in a plot $(40 \times 40 \mathrm{~m})$ that was used as a control (CA C). Contiguously to this control plot, a treated plot (CA T) of similar size, was delimited (Fig. 1b). The basal removed area was $74 \%$. Trees were cut down and ground into detritus to be scattered on the forest floor. Orientation is NW. The slope is not uniform (ranging from $19.6 \%$ to $40 \%$ ), and is lower on the upper and lower hill parts, and higher in the central part. In both sites, three reiterations per treatment were established.

\section{Soil characterisation}

At the HU site, before thinning treatment (2 May, 2012), four points in the control plot and four points in the treated plot distributed along the slope were randomly selected. At each point, a metal frame $(30 \times 30 \mathrm{~cm})$ was used to separately collect the litter layer, the humified organic layer underneath and the top mineral soil layer from $0-15 \mathrm{~cm}$. Then, a soil probe was used to take samples from $15-30 \mathrm{~cm}$ and below $30 \mathrm{~cm}$ whenever possible. Soil depth was around $40 \mathrm{~cm}$ at 
(A) $\mathrm{HU}$

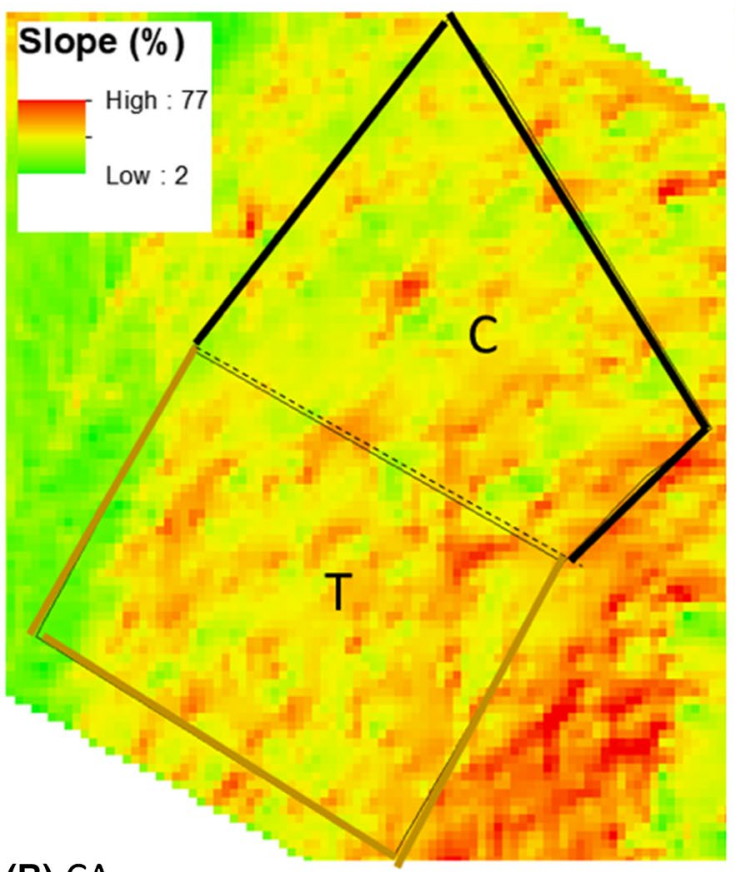

(B) $\mathrm{CA}$

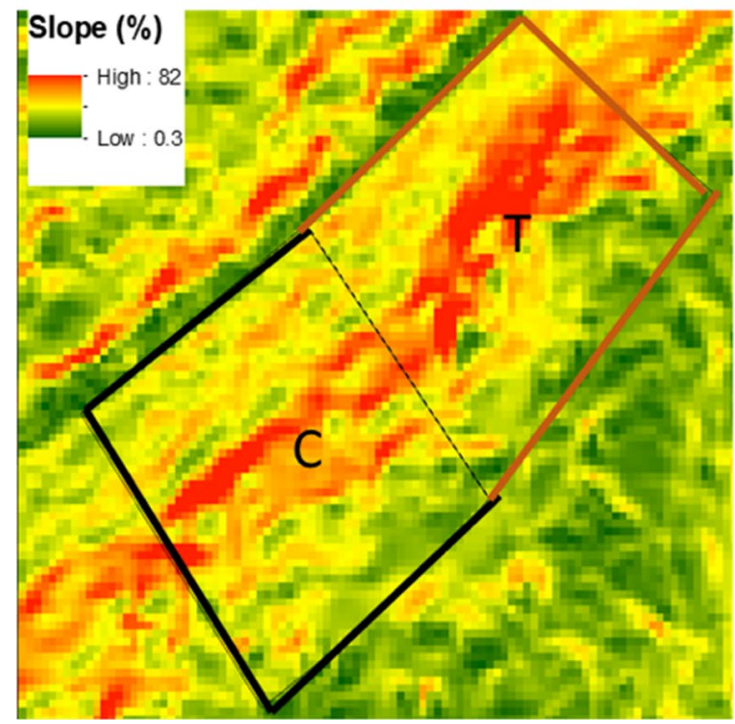

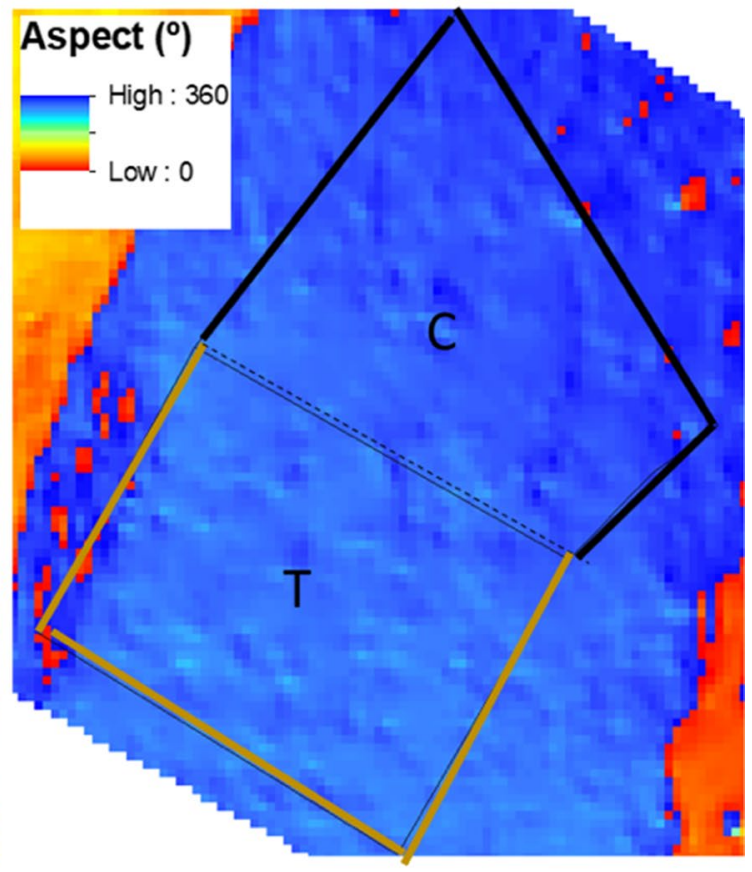

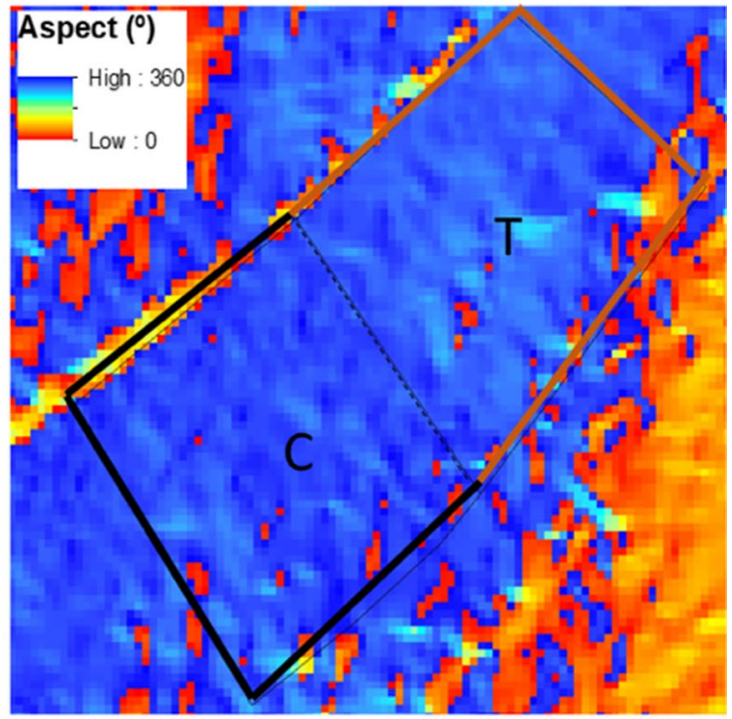

Fig. 1 Slope angle and aspect of (a) La Hunde C (control) and T (treated) plots and (b) Calderona C (control) and T (treated) plots

the bottom of the slope but, as soil is very shallow in the upper slope part, organic matter was found to directly overlie rocks at some points. Samples were weighed and air-dried, weighed again before the different fractions were separated by sieving through a $2-\mathrm{mm}$ mesh. The larger fraction was hand-separated into stones, roots, leaf debris, woody debris and miscellaneous organic fractions. Air-dry soil humidity in the fine fraction was determined in a subsample by drying at $105^{\circ} \mathrm{C}$ until constant weight. In the fine fraction, soil $\mathrm{pH}$ was determined in a 1:2.5 water suspension, inorganic carbonate content was established by the Bernard calcimeter method (MAPA, 1994), and total organic carbon (TOC) by the Walkley-Black method (Nelson and Sommers 1982). At the CA site, a similar scheme was performed after treatment in March 2013, with four points per plot distributed along the slope. All the material inside the frame was taken by separating the litter layer, humified organic layer and mineral soil from 0-5 cm. Deeper samples were taken with a 5-cmdiameter helicoidal probe. Samples were separated and analysed similarly to those from the HU site. Soil characteristics are given in Tables 1 and 2. At HU, soil presents high stoniness $(>50 \%)$, a high calcium carbonate content (18-36.4\%) 
Table 1 Soil characterisation at both experimental sites (La Hunde, $\mathrm{HU}$; Calderona, CA). The forest floor is divided into litter layer and partially decomposed organic residues (L/F layer) fermentation and

\begin{tabular}{|c|c|c|c|c|c|c|c|}
\hline Site & Soil layer & Stoniness (\%) & Humidity (\%) & Root weight (\%) & $\mathrm{CaCO}_{3}(\%)$ & $\mathrm{pH}$ & TOC (\%) \\
\hline \multirow[t]{5}{*}{$\mathrm{HU}$} & L/F layer & $48.4 \pm 10.7$ & $23.2 \pm 7.7$ & & & & \\
\hline & H layer & $57.3 \pm 7.8$ & $20.5 \pm 5.0$ & $0.23 \pm 0.20$ & $18.0 \pm 8.8$ & $7.88 \pm 0.14$ & $11.9 \pm 4.2$ \\
\hline & $0-15 \mathrm{~cm}$ & $64.3 \pm 10.3$ & $15.7 \pm 3.2$ & $0.40 \pm 0.28$ & $20.4 \pm 6.4$ & $8.06 \pm 0.14$ & $6.5 \pm 2.9$ \\
\hline & $15-30 \mathrm{~cm}$ & $65.4 \pm 14.5$ & $11.9 \pm 4.2$ & $0.30 \pm 0.31$ & $28.4 \pm 8.6$ & $8.19 \pm 0.12$ & $5.4 \pm 2.0$ \\
\hline & More than $30 \mathrm{~cm}$ & $55.8 \pm 5.1$ & $15.3 \pm 1.2$ & $0.06 \pm 0.10$ & $36.4 \pm 1.4$ & $8.29 \pm 0.09$ & $2.5 \pm 0.6$ \\
\hline \multirow[t]{5}{*}{$\mathrm{CA}$} & L/F layer & $44.3 \pm 21.7$ & $31.3 \pm 16.4$ & 0 & & & \\
\hline & $0-5 \mathrm{~cm}$ & $33.7 \pm 19.5$ & $18.3 \pm 4.4$ & $0.16 \pm 0.06$ & $27.9 \pm 11.0$ & $8.24 \pm 0.17$ & $5.1 \pm 2.3$ \\
\hline & $5-20 \mathrm{~cm}$ & $20.3 \pm 18.1$ & $19.9 \pm 3.1$ & $0.29 \pm 0.13$ & $34.2 \pm 14.0$ & $8.33 \pm 0.17$ & $2.3 \pm 1.4$ \\
\hline & $20-30$ & $5.3 \pm 4.8$ & $19.6 \pm 2.3$ & $0.05 \pm 0.04$ & $39.6 \pm 9.1$ & $8.49 \pm 0.06$ & $1.0 \pm 0.4$ \\
\hline & More than $30 \mathrm{~cm}$ & $21.7 \pm 4.3$ & $12.3 \pm 1.9$ & $0.01 \pm 0.01$ & $50.3 \pm 0.8$ & $8.51 \pm 0.00$ & $0.6 \pm 0.1$ \\
\hline
\end{tabular}

Values are mean \pm standard deviation ( $\mathrm{n}$ from 3 in the deepest layer to 8 in the surface layer). Sampling dates: HU, 2 May 2012; CA, 20 March, 2013

Table 2 Weight of organic matter $>2 \mathrm{~mm}\left(\mathrm{~g} / \mathrm{m}^{2}\right.$ ) on the organic horizon at both experimental sites (HU, La Hunde before treatment; Calderona after treatment, in the control CA C and the treated, CA T, plots).

\begin{tabular}{llcccc}
\hline Site & Plot & Leaves $\left(\mathrm{g} / \mathrm{m}^{2}\right)$ & Needles $\left(\mathrm{g} / \mathrm{m}^{2}\right)$ & Woody debris $\left(\mathrm{g} / \mathrm{m}^{2}\right)$ & $\begin{array}{l}\text { Miscellane- } \\
\text { ous }>2 \mathrm{~mm} \\
\left(\mathrm{~g} / \mathrm{m}^{2}\right)\end{array}$ \\
\hline HU & & $448 \pm 301$ & & $401 \pm 368$ & $1260 \pm 643$ \\
CA & CA T & & $506 \pm 609$ & $2780 \pm 2579$ & $1825 \pm 513$ \\
& CA C & & $320 \pm 385$ & $159 \pm 131$ & $1573 \pm 948$ \\
\hline
\end{tabular}

Values are mean \pm standard deviation ( $\mathrm{n}$ from 4 in each CA plot to 8 for HU). Sampling dates: HU, 2 May, 2012; CA, 20 March, 2013

and a basic $\mathrm{pH}$ (7.88-8.29). The CA soil presents less stoniness, a higher calcium carbonate content $(27.9-50.3 \%)$, lower total soil organic carbon levels and slightly higher $\mathrm{pH}$ values (8.24-8.51).

The forests present an organic horizon with different morphology, whereas La Hunde shows a well-developed humified layer over the A horizon, in Calderona forest, where organic horizon was developed under an arid climate with $P$. halepensis as main species and possibly affected by the 1992 fire, the organic horizon lack of humified layer, showing only a L layer composed of pinus needles and a thick $F$ layer with partially decomposed vegetal material.

In the litter layer, oak leaves prevailed at HU vs. pine needles at CA (Table 2). At CA, where all the residue was left on soil, treatment increased the woody debris weight 18-fold compared to the control plot.

\section{Soil respiration}

The experimental design was a complete block design following a stratified random sampling scheme (Pennock et al. 2008) with two treatments (thinning and untreated control). Both the thinned and control areas were split into three similar sized blocks from upslope to downslope. In the three previously defined blocks, three PVC collars (10 $\mathrm{cm}$ in diameter, $5 \mathrm{~cm}$ deep) were installed to measure the Rs efflux in the same place throughout the study. Collars were placed $3 \mathrm{~cm}$ into soil at each position. An EGM-4 environmental gas monitor (PP System Company, Amesbury, MA, USA) was used to measure periodically the $\mathrm{CO}_{2}$ efflux after the treatment until November 2014; and from November 2015 to the end of 2016. At the HU site, treatment was performed in May 2012 and respiration measurements began in September 2012. At CA, Rs measurements began in July 2013.

Nearly, all our measurements were taken at midday, between 11:00 and 13:00 h GMT + 1, with a 1-2-month interval. Soil humidity and soil temperature were recorded simultaneously with Rs near collars from a depth of 0-6 cm with an HH2 humidity meter and a WET-2 sensor (Delta-T Devices Ltd, UK). Air temperature measurements were taken above the canopy with T, RH sensors (Decagon Devices, Pullman, USA), connected to a data-logging system (CR1000, Campbell Sci., UT, USA). Air data were recorded at $10-$ min time intervals. 


\section{Heterotrophic activity}

Laboratory heterotrophic activity measurements were performed on the soil samples taken from the surface mineral soil in HU plots. Soil sampling was conducted bimonthly from December 2012 and ended in June 2013 at the HU site. In each plot (HU C and HU T), nine samples were taken from $0-10 \mathrm{~cm}$ after removing the organic horizon. After being sieved through a $2-\mathrm{mm}$ mesh, soil samples, were incubated at $25^{\circ} \mathrm{C}$ and field humidity to analyse laboratory respiration. A subsample of each sieved soil was dried to $105^{\circ} \mathrm{C}$ to determine gravimetric water content. The remainder was stored at $4{ }^{\circ} \mathrm{C}$ until respiration was measured. $\mathrm{CO}_{2}$ evolution was measured in sealed flasks with rubber septa by an infrared sensor PBI Dansensor, and was used as an indicator of heterotrophic activity ( $\mathrm{Ha}$ ) of surface mineral soil. The incubation flasks were aerated daily to prevent restriction in respiration by lack of oxygen. Heterotrophic activity is performed in altered soil samples and results are expressed in mass basis.

In these samples, water-soluble organic carbon (WSOC) was determined in the $(1: 2.5)$ aqueous soil extract obtained after $30 \mathrm{~min}$ of mechanical shaking, centrifugation at 2,500 rpm for $5 \mathrm{~min}$ and filtration through Whatman 42 paper filter. The WSOC in the extracts was estimated by $\mathrm{K}_{2} \mathrm{Cr}_{2} \mathrm{O}_{7}$ oxidation in concentrated $\mathrm{H}_{2} \mathrm{SO}_{4}$ (Yakovchenko and Sikora 1998).

\section{Spatial distribution of forest floor depth}

Spatial distribution of forest floor depth was characterised in January and February 2017 at the HU site and the CA site, respectively. In nine points per plot and close to each respiration collar, all the forest floor material was collected from an area covering $12 \mathrm{~cm} \times 12 \mathrm{~cm}$. Forest floor thickness was recorded at each point. After air drying, each sample was separated into different fractions: stones, roots, plant material over $4 \mathrm{~mm}$ and the fine fraction under $4 \mathrm{~mm}$. These fractions were dried at $65^{\circ} \mathrm{C}$ for at least $48 \mathrm{~h}$ before being weighed. At each point, a mineral soil sample underneath was collected from $0-15 \mathrm{~cm}$ and sieved at $2 \mathrm{~mm}$ for routine analysis purposes. In these samples, roots were hand-separated and root dry weight was recorded to gravimetrically obtain the proportion of roots.

\section{Data analysis and statistics}

Datasets were tested before analysing for normality, performing the Kolmogorov-Smirnoff test and homogeneity of the variance (Levene's test), and were log-transformed whenever necessary to improve normality and homocedasticity. Thinning effects were assessed by comparing the $\mathrm{T}$ and $\mathrm{C}$ plots for soil respiration, soil humidity and temperature on each sampling date. When the distribution parameters were non-normally distributed, a one-way Kruskal-Wallis test was performed using treatment as the main factor. Differences at $P<0.05$ were considered to be statistically significant. Slope effects were assessed by comparing the mean values among the three positions along the slope (1 ridgetop, 2 mid-slope, 3 bottom).

The effects of thinning treatment ( $\mathrm{T}$ and $\mathrm{C}$ ) and position along the slope ( 1 ridgetop, 2 mid-slope, 3 bottom) on heterotrophic activity, soluble organic carbon (WSOC) and forest floor characteristics were analysed by a multifactor ANOVA. The effects of humidity, spatial position and substrate availability on the Ha values were tested by an ANCOVA analysis using WSOC and humidity as covariables. These statistical analyses were performed with Statgraphics Centurion XVII. When a significant interaction was found between explanatory variables, a separate oneway ANOVA analysis with Fisher's LSD post hoc test was performed.

The relations between field $\mathrm{Rs}$ and soil climate variables were investigated with the general linear model (GLM) proposed by Tang et al. (2005b), which has also been employed in other forest ecosystems (Olajuyigbe et al. 2012). A multivariate analysis with two independent variables (soil temperature and water content), and a categorical variable representing the interaction of treatment and position along the slope, was performed. An exponential function was applied to model the regulatory effect of surface (0-6 cm depth), soil temperature $\left(\mathrm{Ts},{ }^{\circ} \mathrm{C}\right)$ and humidity $(\theta, \%)$ on Rs (Rs, $\left.\mu \mathrm{mol} \mathrm{C} \mathrm{m}^{-2} \mathrm{~s}^{-1}\right)$.

$R s=\beta_{0} e^{\beta_{1} T s} e^{\beta_{2} \theta+\beta_{3} \theta^{2}}$

where $\beta_{0}, \beta_{1}, \beta_{2}$ and $\beta_{3}$ are fitting parameters. The equation can be log-transformed to a linear model:

$\ln (R s)=\ln \left(\beta_{0}\right)+\beta_{1} T s+\beta_{2} \theta+\beta_{3} \theta^{2}$

where $\beta_{0}$ is basal respiration, which is related to the decomposable substrate size. It is the value of Rs when $\beta_{1} T s=0$ or $\mathrm{Ts}=0^{\circ} \mathrm{C}$ and $\beta_{2} \theta+\beta_{3} \theta^{2}=0$.

$\beta_{1}$ is related to temperature sensitivity factor $\mathrm{Q}_{10}$ as:

$\beta_{1}=\frac{\ln Q_{10}}{10}$

$\mathrm{Q}_{10}$ is defined as the increment in the Rs rate when soil temperature increases $10^{\circ} \mathrm{C}$. To obtain more information about the spatial pattern of Rs distribution along the slope and its interrelation with thinning treatment, a combined variable was defined with six levels (T1, T2, T3, C1, C2, C3), where 1, 2 and 3 represented the three identified slope strata (ridgetop, mid-slope, bottom) in each plot. Differences in the Rs induced by 
changes in microclimatology and their interaction with the time elapsed after treatments were tested using the GLM analysis by taking the post-treatment period (short term, 1-2 years; mid-term, 3-4 years) and the block and treatment combination as factors, and soil temperature, humidity and squared humidity as covariables. This analysis was carried out with R 3.3.3 (R Development Core Team 2017).

\section{Results}

\section{Soil respiration, soil temperature and soil humidity in the thinned and control plots}

The Rs rate displayed significant seasonal variability. In the HU C plot (Fig. 2a), the maximum respiration rate $5.06 \pm 1.89 \mu \mathrm{mol} \mathrm{C} \mathrm{m}{ }^{-2} \mathrm{~s}^{-1}$ was recorded in September 2014 and the minimum value of $0.65 \pm 0.26 \mu \mathrm{mol} \mathrm{C} \mathrm{m} \mathrm{C} \mathrm{s}^{-1}$ in January 2016. In the HU T plot, the maximum respiration value $\left(5.58 \pm 6.07 \mu \mathrm{mol} \mathrm{C} \mathrm{m}^{-2} \mathrm{~s}^{-1}\right)$ was recorded in the first
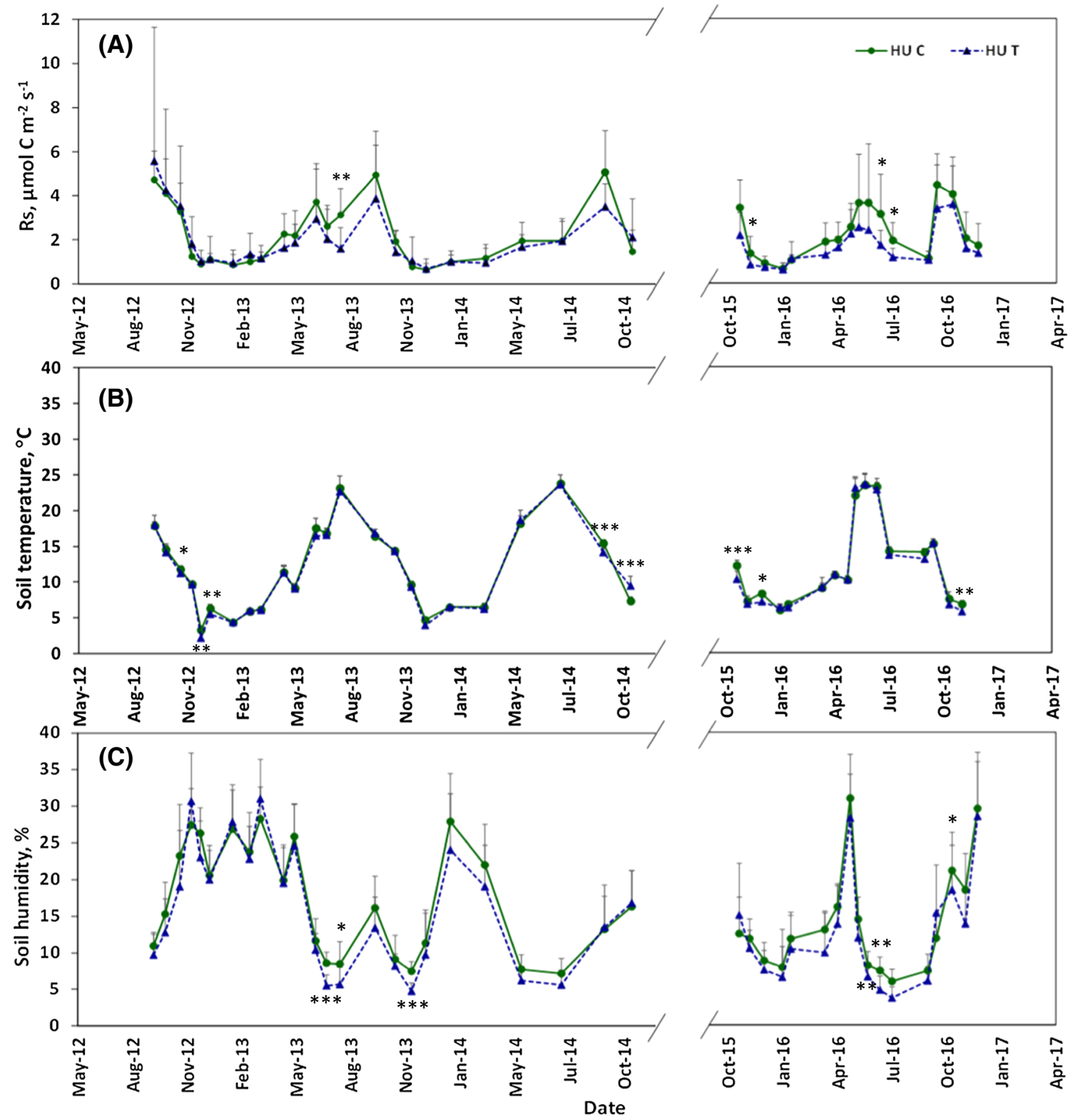

Fig. 2 Seasonal variation in a soil respiration, Rs; b soil temperature; c soil humidity in La Hunde oak forest. Points represent the mean values and error bars standard deviation $(\mathrm{n}=9)$. *, ** and *** significant differences in the $\mathrm{C}$ (control) or $\mathrm{T}$ (thinning treatment) plots $(p<0.05$, $p<0.01$ and $p<0.001$, respectively) (Rs data were log-transformed before comparing the mean values) 
post-treatment year in September 2012 and the minimum one $\left(0.61 \pm 0.31 \mu \mathrm{mol} \mathrm{C} \mathrm{m} \mathrm{C} \mathrm{s}^{-1}\right)$ in January 2015 . The HU $\mathrm{T}$ plot obtained significantly higher standard deviation values than the control in the first post-thinning year.

Soil temperature showed marked seasonal variation, with maximum values in July and minimum values in January (Fig. 2b). Soil humidity also had a strong seasonal component (Fig. 2c) associated with rainfall, with maximum values in winter and minimum ones in summer. The changes in the rainfall pattern of the studied years vastly differed, with 2013 and 2014 being very dry years (del Campo et al. 2018).
In 2014, soil began to dry out in April and the dry period lasted until September. Conversely as 2012 and 2016 were wetter, surface horizon humidity remained high until the end of spring.

The maximum value of respiration rates at site CA were $5.45 \pm 1.63 \mu \mathrm{mol} \mathrm{C} \mathrm{m}{ }^{-2} \mathrm{~s}^{-1}$ in September 2014 in the CA T plot, and 6.26 $\pm 3.94 \mu \mathrm{mol} \mathrm{C} \mathrm{m} \mathrm{C}^{-2} \mathrm{~s}^{-1}$ in November 2015 in the CA $\mathrm{C}$ plot (Fig. 3a). The minimum respiration values were $0.56 \pm 0.42 \mu \mathrm{mol} \mathrm{C} \mathrm{m}^{-2} \mathrm{~s}^{-1}$ for the CA $\mathrm{T}$ plot and $0.67 \pm 0.47 \mu \mathrm{mol} \mathrm{C} \mathrm{m}{ }^{-2} \mathrm{~s}^{-1}$ for the CA C plot, both recorded in November 2013. As a general trend, the Rs at both study

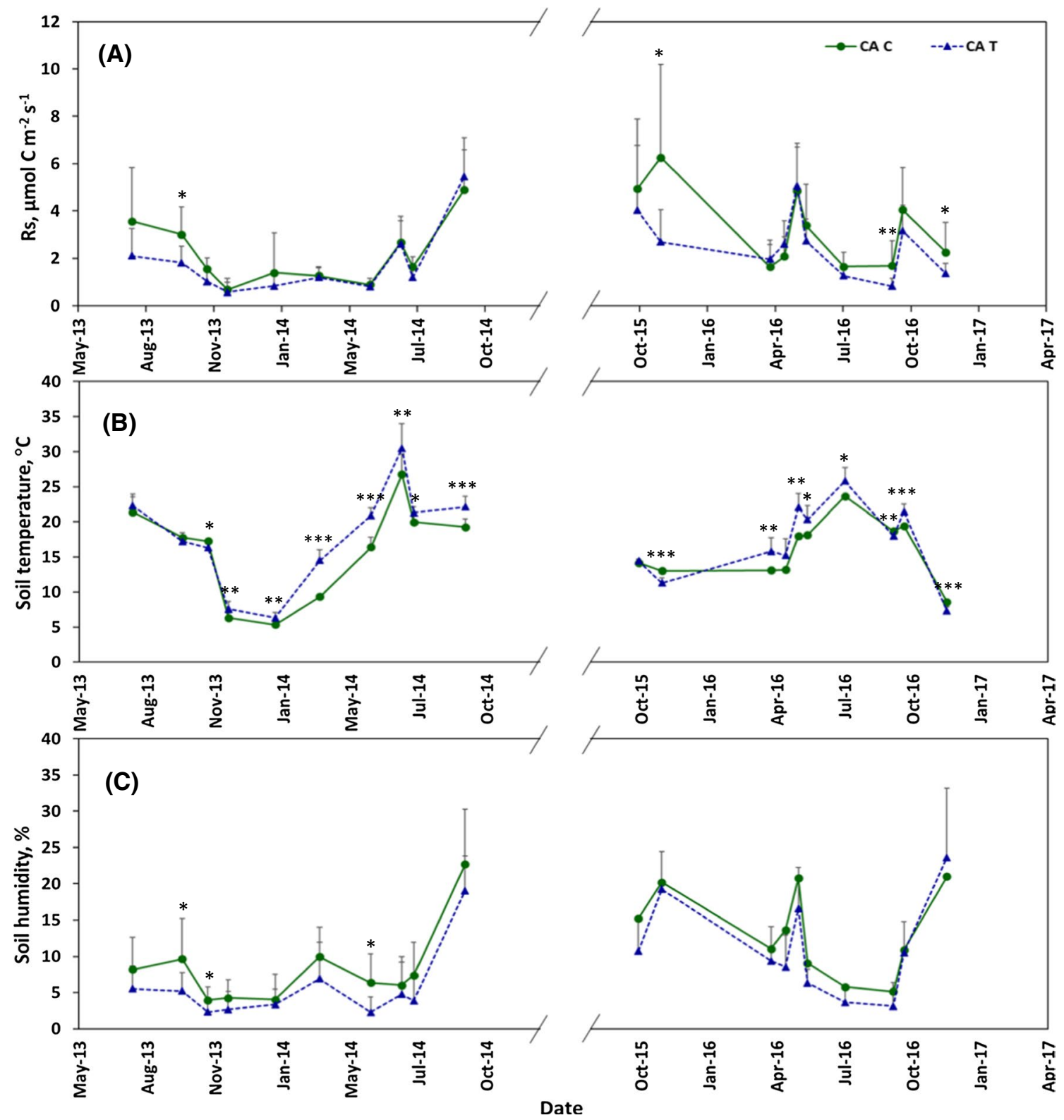

Fig. 3 Seasonal variation in: a soil respiration, Rs; b soil temperature; c soil humidity in the Calderona pine forest. Points represent the mean values and error bars standard deviation $(\mathrm{n}=9) . *$, ** and
*** significant differences in the $\mathrm{C}$ (control) or $\mathrm{T}$ (thinning treatment) plots ( $p<0.05, p<0,01$ and $p<0,001$, respectively) (Rs data were log-transformed before comparing the mean values) 
sites was low in winter due to low soil temperature, and began to increase in spring before lowering when soil dried in summer. Soil temperature and humidity (Fig. 3b,c) presented similar temporal variations to those of the HU plots.

The highest Rs values were obtained in September, which coincided with the first rains after summer drought, and lasted while soil temperature was over $10^{\circ} \mathrm{C}$.

\section{Thinning effect on soil respiration and microclimate. Comparison of forests}

The mean Rs value in the HU C plot $(2.17 \pm 1.65 \mu \mathrm{mol} \mathrm{C}$ $\mathrm{m}^{-2} \mathrm{~s}^{-1}$ ) was $13 \%$ higher than that recorded in the HU T plot. In La Hunde forest, after treatment, soil respiration remained slightly higher in the treated plot until February 2013, although differences were not statistically significant. Soil respiration was significantly higher in the control plot on four dates (17/07/2013, 27/11/2015, 26/06/16, 19/07/16), and three of these dates correspond to the beginning of summer, this being the active tree growth season. This effect was not observed in the driest year (2014), when respiration values were quite low.

Surface soil moisture was significantly higher in the control plot on five dates. Soil temperature was significantly higher in the control plot on eight dates, but differences between plots were usually very small.

In the CA forest, the mean Rs value was $2.71 \pm 2.19 \mu \mathrm{mol}$ $\mathrm{C} \mathrm{m}^{-2} \mathrm{~s}^{-1}$ in CA C, which was $26 \%$ higher than the corresponding $\mathrm{CA} T$ plot value. Soil respiration was generally higher in the $\mathrm{C}$ plot, although these differences were significant only on four dates recorded in autumn after summer drought.

Soil temperature was generally higher in the T plot, and this difference was significant on almost all the dates despite us also usually starting to measure in the $\mathrm{T}$ plot in this forest.
In CA, the biggest differences in temperature between the treated and control plots appeared in spring following thinning treatment.

\section{Topographical effects}

Topography differentially affected soil respiration in relation to treatment (Fig. 4). Soil respiration presented a thinningposition interaction along the slope. In the thinned plot, soil respiration was higher in the mid-slope position at both sites. In the control plot of La Hunde forest, Rs was higher at the ridgetop and, in the control plot of the Calderona forest, Rs was significantly higher in the bottom position.

Regarding the topographical effect, a humidity gradient along the slope was found with higher soil humidity values in the bottom position (11.36\% in CA T, $13.97 \%$ in CA C in the lower part vs. $7.11 \%$ and $7.50 \%$ in the upper part in of CA T and CA C, respectively). At the HU site, this gradient was significant only in the treated plot (Table 3). Topography did not induce any significant effect on soil temperature.

\section{Thinning and heterotrophic activity}

In the samples used for the heterotrophic activity measurements, mineral soil humidity ranged from 7.45 to $72.51 \mathrm{~g}$ water/100 $\mathrm{g}$ of dry soil, and was considerably higher than those values found in the bulk surface soil layer. With the ANCOVA analysis (Table 4), soil humidity explained 46.5\% of the variability in the Ha rates, and substrate (WSOC) availability explained a further $13.7 \%$ of the variance in Ha.

The effect of thinning on Ha all along the topographical position (Fig. 5) showed distinctive behaviour between the control and treated plots, with a significant increase in heterotrophic activity, $\mathrm{Ha}$, and water-soluble organic carbon, WSOC noted for the mid-slope block in the treated plot.

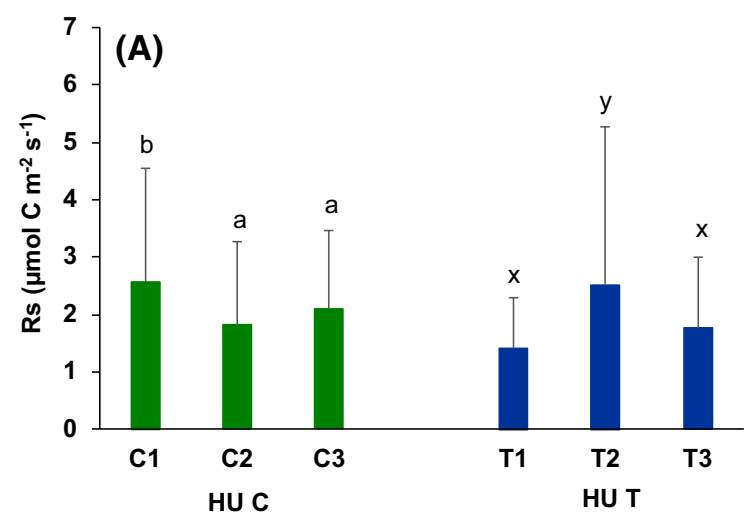

Fig. 4 Mean values and standard deviation for soil respiration (Rs) in the control $(\mathrm{C})$ and thinned $(\mathrm{T})$ plots in different positions along the slope (1 ridgetop, 2 mid-slope, 3 bottom) in the (a) HU, La Hunde forest and (b) CA, Calderona forest. Values presented are mean and

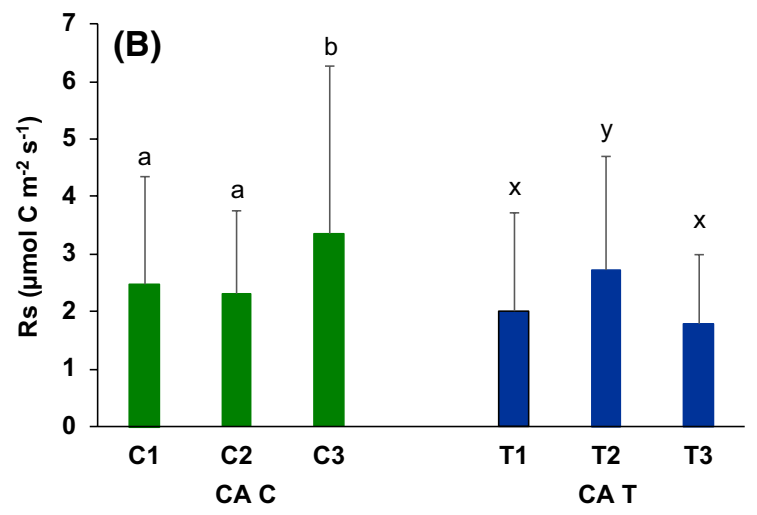

standard deviation. Lower case letters indicate significant differences in the mean values $(p<0.05)$ among blocks according to LSD Fisher, independently for each plot 
Table 3 Mean soil surface temperature, Ts, and soil surface humidity, Hs, in the thinned and control plots in different positions along the slope (1 ridgetop, 2 mid-slope, 3 bottom) in treated, T, and control, C, plots.

\begin{tabular}{|c|c|c|c|c|c|}
\hline \multirow[t]{2}{*}{ Site } & \multirow{2}{*}{$\begin{array}{l}\text { Block (slope } \\
\text { position) }\end{array}$} & \multicolumn{2}{|c|}{ Temperature $\left({ }^{\circ} \mathrm{C}\right)$} & \multicolumn{2}{|l|}{ Humidity (\%) } \\
\hline & & $\mathrm{T}$ & $\mathrm{C}$ & $\mathrm{T}$ & $\mathrm{C}$ \\
\hline \multirow[t]{4}{*}{$\mathrm{HU}$} & 1 & $11.57 \pm 6.17$ & $11.77 \pm 6.07$ & $12.95 \pm 8.06 a$ & $16.29 \pm 8.93$ \\
\hline & 2 & $12.10 \pm 6.18$ & $12.05 \pm 6.30$ & $13.86 \pm 9.52 a$ & $15.02 \pm 8.27$ \\
\hline & 3 & $11.61 \pm 6.30$ & $11.92 \pm 5.61$ & $17.57 \pm 9.57 b$ & $16.93 \pm 7.97$ \\
\hline & & $\mathrm{T}$ & $\mathrm{C}$ & $\mathrm{T}$ & $\mathrm{C}$ \\
\hline \multirow[t]{3}{*}{$\mathrm{CA}$} & 1 & $17.59 \pm 6.41$ & $16.82 \pm 6.17$ & $7.11 \pm 6.94 a$ & $7.50 \pm 6.26 a$ \\
\hline & 2 & $17.28 \pm 5.98$ & $15.63 \pm 5.58$ & $6.83 \pm 6.95 a$ & $10.95 \pm 7.27 b$ \\
\hline & 3 & $17.74 \pm 6.59$ & $15.31 \pm 4.94$ & $11.36 \pm 7.72 b$ & $13.97 \pm 7.85 c$ \\
\hline
\end{tabular}

Different letters indicate statistically significant mean differences $(\mathrm{p}<0.05$ in bold)
Table 4 The ANCOVA of heterotrophic activity, Ha (expressed as $\mu$ mol kg ${ }^{-1}$ day $^{-1}$ ), obtained by lab incubation with La Hunde samples at $25^{\circ} \mathrm{C}$ vs. treatment, block, soil humidity and water-soluble organic carbon (WSOC)

$\begin{array}{lll}\% \text { total variance } & \text { F ratio } & \text { P value } \\ \text { explained by }\end{array}$

Effects

\begin{tabular}{lrrr} 
A. Treatment & 1.5 & 4.89 & 0.030 \\
B. Block & 1.9 & 3.12 & 0.049 \\
Interaction A*B & & 1.62 & 0.204 \\
Covariables & & & \\
Humidity & 46.5 & 152.52 & 0.000 \\
WSOC & 13.7 & 44.88 & 0.000 \\
\hline
\end{tabular}

\section{Effect of thinning on the soil organic horizon}

The mean organic horizon thickness and water depth values (Fig. 6a,b) were higher in HU than in CA, and wide variability appeared between blocks. Thinning increased the organic layer depth due to the incorporation of chopped woody debris into the soil surface, and this effect was stronger in

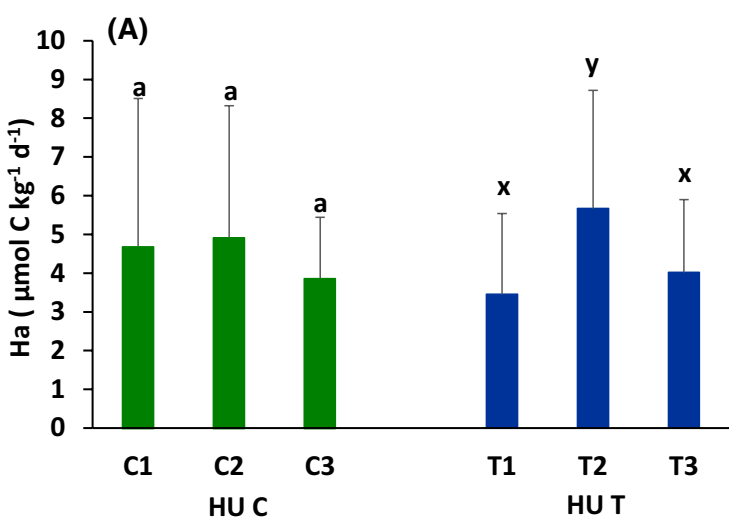

Fig. 5 Effect of position on the slope and thinning treatment in (a) heterotrophic activity, $\mathrm{Ha}$ and (b) water-soluble organic carbon, WSOC in La Hunde control, HU C and treated, HU T plots: control top, $\mathrm{C} 1$, control middle, $\mathrm{C} 2$, control bottom, $\mathrm{C} 3$, treated top, $\mathrm{T} 1$,
CA. The organic layer depth in the treated plot was deeper in the middle position at both sites, which indicates irregular debris distribution from the thinning treatment. The quantity of organic matter strongly impacted the water retained by the organic horizon (Fig. 6b). As the organic layer had a higher degree of humification in HU, it created favourable root growth conditions because it enhanced the root percentages in this zone (Fig. 7). At HU, fine roots were also found in the organic horizon.

\section{Influencing factors for variation in Rs}

A general linear analysis was performed using the model proposed by Tang et al. (2005b) (Table 5). The variables that most significantly explained variation in Rs were soil temperature in the dry subhumid forest (the F-value was 310 for $\mathrm{HU}$ ) and soil humidity in the semiarid forest (F-value was 119 and 38 in CA for humidity and square humidity, respectively). The soil climatic variables accounted for the greatest percentage of total Rs variability: soil temperature explained $24.1 \%$ of total Rs variability in the dry subhumid forest and soil humidity explained $24.6 \%$ of total Rs

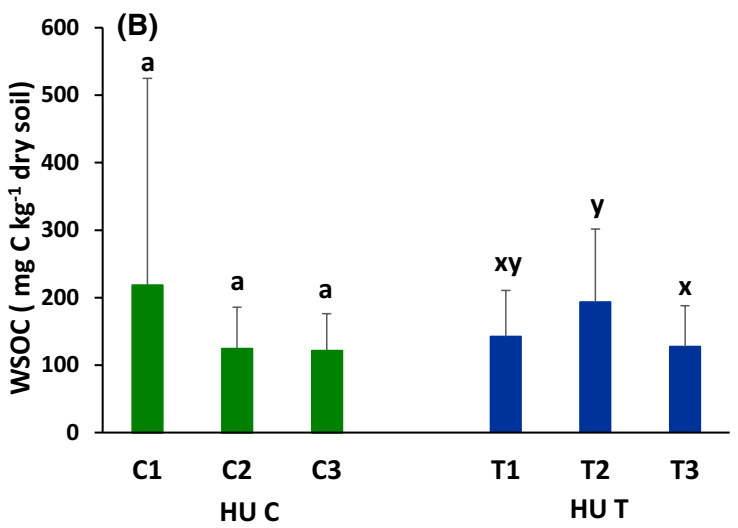

treated middle, $\mathrm{T} 2$ and treated bottom, T3. Bars represent the mean and standard deviation. Lower case letters indicate significant differences in the mean values among blocks according to LSD Fisher, independently for each plot 

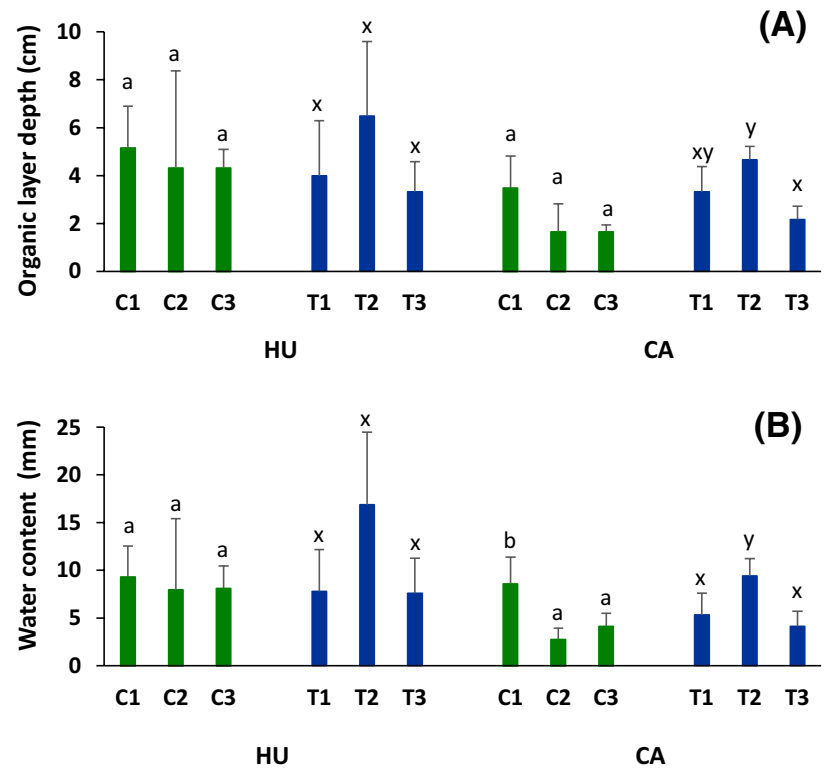

Fig. 6 a Organic layer depth $(\mathrm{cm})$ and $\mathbf{b}$ the water content $(\mathrm{mm})$ that remained in the organic layer on the sampling date (beginning of 2017) in La Hunde (HU) and Calderona (CA): control top, C1, control middle, $\mathrm{C} 2$, control bottom, $\mathrm{C} 3$, treated top, $\mathrm{T} 1$, treated middle, T2 and treated bottom, T3. Bars indicate the mean values and standard deviation $(\mathrm{n}=3)$

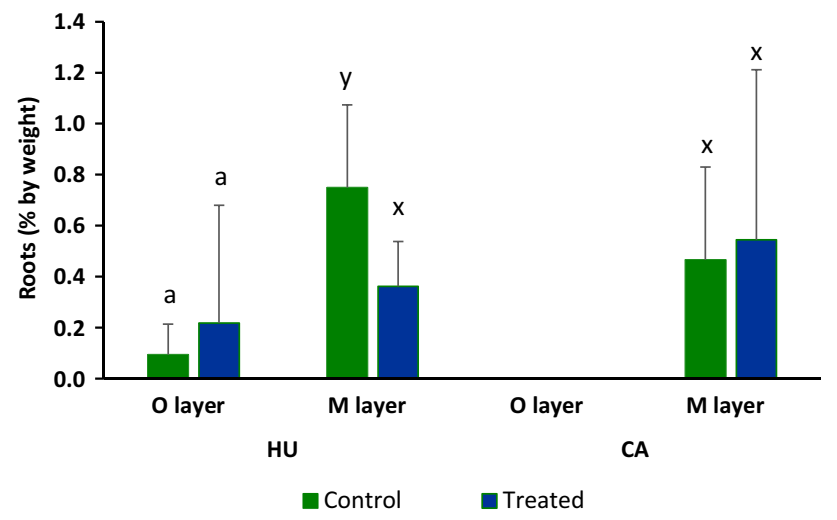

Fig. 7 Percentage of the root dry weight in the organic layer (O layer) and surface mineral soil $(0-10 \mathrm{~cm}) \mathrm{M}$ layer in La Hunde and Calderona plots (sampling date in 2017). Bars indicate the mean values and standard deviation $(\mathrm{n}=9)$

variability in the semiarid forest. The topographical effect was also very significant at both sites (F-value of 15.0 for $\mathrm{HU}$ and 5.1 for CA). Differences between sites were the significant effect of period after treatment on CA Rs, and the significant interaction between temperature sensitivity and treatment observed in HU. Otherwise, no other significant interactions were found at either site.

The position along the slope had significant effects on Rs, but gave contrasting results in plots $\mathrm{T}$ and $\mathrm{C}$ (Table 6).
At both sites, the highest basal respiration $\left(\beta_{0}\right)$ was found in the treated plot in the mid-slope position. The regression slopes in relation to soil humidity and square of soil humidity were similar in both areas, and were also similar to the values reported by Tang et al. (2005a). In HU, significant differences in temperature sensitivity (obtained from $\beta_{1}$ according to Eq. 3) between the $\mathrm{HU} C\left(\mathrm{Q}_{10}=2.67\right)$ and $\mathrm{HU}$ $\mathrm{T}$ plots $\left(\mathrm{Q}_{10}=\right.$ equal to 2.08). The $\mathrm{Q}_{10}$ value in $\mathrm{CA}$ (1.87) indicates a lower temperature sensitivity in this site. Overall, the percentage of variance explained by the spatial and microclimate variables was higher than $41 \%$ in both areas.

\section{Discussion}

In 2012, thinning treatment was performed in two different Mediterranean forest stands to analyse thinning effects on forest resilience. Both stands are located in mountain areas with similar slopes and aspects, although the two forests' climate characteristics and main species differed. Rs was measured from September 2012 to November 2014 and from November 2015 to December 2016 in HU, whereas in CA were performed also in two periods but the first one began in July 2013. The seasonal Rs distribution at both study sites gave low values in winter due to low soil temperatures, which began to rise in spring, but lowered as soil dried in summer. These findings indicate that with a semiarid climate, soil respiration is controlled by both soil humidity and soil temperature.

Our results revealed a general decrease in Rs in the thinned plots at both sites, although the effect of treatment on Rs was stronger in CA in the first year after thinning. In this same year (2012), Rs was higher in the HU T plot vs. HU C, but Rs was considerably lower in CA T than in CA $\mathrm{C}$ in 2013. Soil respiration was significantly higher in the control plot of the HU forest on four dates, three of which corresponded to the beginning of summer. At the CA site, the Rs in the control plot was significantly higher in autumn after summer drought, which indicates that root activity and autotrophic respiration brought about higher respiration rates in the control plots during active plant-growing periods.

Several reasons explain the differences in response to thinning between both forests. In HU, the silvicultural treatment was moderate ( $41 \%$ of the basal area removed) compared to CA ( $74 \%$ of the basal area removed). As Zhao et al. (2019) reported, thinning intensity is an important factor because after thinning, Rs only increase under light and in the moderate thinning treatments, probably due to the induced increased root activity, which cannot be compensated by decreasing root density after intense thinning.

Thinning treatment was performed earlier at HU (May 2012), and was done in November 2012 at CA. For this reason, tree responses to thinning during the growing 
Table 5 Statistical significance ( $F$ ratio and $P$ value) of the factors and variables implicated in Rs (log-transformed) in Calderona, CA and La Hunde, HU according to the GLM analysis. Factors are the block and treatment combination (T1, $\mathrm{T} 2, \mathrm{~T} 3, \mathrm{C} 1, \mathrm{C} 2, \mathrm{C} 3)$ and period after treatment.

\begin{tabular}{|c|c|c|c|c|c|c|c|c|c|}
\hline & \multirow[t]{2}{*}{ Source of variation } & \multicolumn{4}{|c|}{$\mathrm{HU}$} & \multicolumn{4}{|c|}{ CA } \\
\hline & & df & F ratio & $\mathrm{P}$ value & $\begin{array}{l}\% \\
\text { explained } \\
\text { variance }\end{array}$ & df & F ratio & $\mathrm{P}$ value & $\begin{array}{l}\% \\
\text { explained } \\
\text { variance }\end{array}$ \\
\hline \multirow[t]{2}{*}{ Factors } & Combination & 5 & 15.0 & $<0.001$ & 5.8 & 5 & 5.1 & $<0.001$ & 5.4 \\
\hline & Period & 1 & 1.2 & NS & 0.1 & 1 & 5.0 & 0.026 & 0.8 \\
\hline \multirow[t]{3}{*}{ Variables } & Temperature & 1 & 309.7 & $<0.001$ & 24.1 & 1 & 81.2 & $<0.001$ & 12.8 \\
\hline & Humidity & 1 & 85.0 & $<0.001$ & 6.6 & 1 & 119.1 & $<0.001$ & 18.7 \\
\hline & Sq.humidity & 1 & 85.7 & $<0.001$ & 6.7 & 1 & 37.6 & $<0.001$ & 5.9 \\
\hline \multirow[t]{3}{*}{ Interactions } & TreatxTemp & 1 & 10.2 & $<0.001$ & 0.8 & 1 & 0.1 & NS & \\
\hline & TreatxHumi & 1 & 0.0 & NS & & 1 & 0.2 & NS & \\
\hline & TreatxPeriod & 1 & 0.2 & NS & & 1 & 0 & NS & \\
\hline
\end{tabular}

The considered variables are surface soil humidity, square soil humidity and soil temperature (NS, not significant)
Table 6 Mean basal respiration $(\beta 0)$ values for each slope position (control top, $\mathrm{C} 1$, control middle, $\mathrm{C} 2$, control bottom, C3, treated top, T1, treated middle, T2 and treated bottom, T3) at La Hunde (HU) and Calderona (CA) forests for the first period after treatment and the regression coefficients for temperature $\left(\beta_{1}\right)$, humidity $\left(\beta_{2}\right)$ and square humidity $\left(\beta_{3}\right)$

\begin{tabular}{llllc}
\hline Factor & Plot & Subplot & HU & CA \\
\hline$\beta_{0}$ & & C1 & 0.210 & 0.293 \\
& & C2 & 0.148 & 0.268 \\
& C3 & 0.173 & 0.277 \\
& & T1 & 0.196 & 0.286 \\
& & T2 & 0.285 & 0.385 \\
& & T3 & 0.202 & 0.185 \\
$\beta_{1}$ & $\mathrm{C}$ & & 0.097 & 0.064 \\
& $\mathrm{~T}$ & & 0.076 & 0.064 \\
$\beta_{2}$ & & & 0.1155 & 0.1181 \\
$\beta_{3}$ & & & -0.0024 & -0.0025 \\
$\mathrm{R}^{2}$ & & & 0.4322 & 0.4174 \\
\hline
\end{tabular}

season began in 2012 for $\mathrm{HU}$ and in 2013 for CA. Both years vastly differed from a hydrological point of view. Species' response to thinning also differed. Holm oak is a resprouting species with considerable belowground biomass, particularly after many years of coppicing in the past (Ducrey and Tunel 1992). After moderate thinning in HU and good hydrological conditions, the canopy cover was highly dynamic; a more open canopy and less water competitiveness trigger the growth of not only the remaining trees, whose resprouting was notably enhanced by treatment, but also of understory brush (del Campo et al. 2018; 2019). In the CA forest where Aleppo pine is the main species, the increased growth of roots from the remaining trees during the next growing season after thinning was delayed because the year following treatment was extremely dry.
Thinning also change soil macroclimate. Soil moisture was generally higher in the $\mathrm{C}$ plot in both sites but significant differences only appeared when soil was dry, and could be explained by the higher tree density in the $\mathrm{C}$ plot, which enhances shading and limits evaporation losses under high evaporative demand. As thinning represents a shift from a closed canopy in the control to a more opened ventilated forest structure, direct evaporation from soil is promoted by lowering surface water contents.

Regarding soil temperature in HU differences between plots were usually very small although soil temperature was significantly higher in the control plot in the autumn measurements, when soil cools, and could be due to an experimental artifice as measurements were normally taken firstly in the treated plot and then in the C plot. In CA, soil temperature was generally higher in the T plot, and this difference was significant on almost all the dates. In CA with the biggest differences in temperature between the treated and control plots appearing in the spring following thinning treatment. The contrast between both forests, with similar slopes and orientations, was due mainly to thinning intensity, which was higher in CA. Both forests also differ in tree canopy structure between both oak and pine species, which induces changes in ground shading.

Many studies about thinning effects on Rs have been carried out on gentle slopes (Tang et al. 2005b; Lopez-Serrano et al. 2016) or slopes are not reported in them (Cheng et al. 2015). The wide diversity in soil properties on steep slopes leads to heterogeneity in chemical, structural and functional traits, which contributes to the spatial heterogeneity of Rs (Mallik and Hu 1997; Ma et al. 2004; Martin and Bolstad 2009). We observed a marked interaction between position along the slope and silvicultural treatment, and not only in the total Rs measured under field conditions, but also in $\mathrm{Ha}$ under controlled laboratory conditions. When comparing position along the slope, the mid-slope block in the treated 
plots showed significantly higher Rs and Ha values. Other authors (Arias-Navarro et al. 2017) have found that position along the slope has significant effects on soil $\mathrm{CO}_{2}$ or $\mathrm{N}_{2} \mathrm{O}$ fluxes, regardless of the effect of topography on soil microclimate variables. The study by Ohashi and Gyokusen (2007), who analysed the relation between Rs variability and slopes, showed a spatial pattern with higher values located in the mid- or upper slope part. Our experiment indicated that soil respiration significantly increased in the mid-slope position in the treated plots, probably in relation to either different species or residue covers along the slope, or the more soluble organic matter or nutrients being transported along the slope in the treated plots (Fang et al. 2009). An additional factor that increases variability is the influence of slope on microclimate conditions: under our climate conditions, a humidity gradient appeared with drier conditions in the upper slope part.

We found that heterotrophic respiration measured in HU mineral soil is dependent on soil humidity and soluble organic carbon. These findings suggest that this soil organic matter fraction was an easily available substrate to soil microorganisms and is, thus, an important heterotrophic Rs component. Heterotrophic respiration is controlled mainly by climate and substrate availability, of which the latter very much depends on organic carbon accumulation in soil. One early thinning effect is an increasing amount of the woody debris normally scattered on the ground. In the HU area, litter layer presented a high degree of humification and contributed to retain water by the organic horizon. After thinning, the organic layer depth had a similar mean value in both HU C and HU T, but heterogeneity was greater in the treated plot with higher values in the mid-slope part. The organic residue left in soil after thinning treatment as coarse woody debris (CWD) brought about a temporal increase in dissolved organic carbon shortly after treatment in the HU plots (Bautista et al. 2015; Lull et al. 2020). This scenario indicates that residue may generate high biological activity areas by the release of carbon-rich dissolved organic matter (DOM) (Spears and Lajtha 2004; Goldin and Hutchinson 2013). Conversely in the CA plots, the organic matter level that accumulated on the soil surface before the treatment was very low compared to HU probably due to this area was fired in 1992. It was reported that wild fires decreased litter layer leaving only one third to one half of the pre-fire content (Boerner 1983). As a consequence of the strong thinning treatment, the CA C plot had a litter layer that doubled in CA $\mathrm{T}$ after treatment in the treated plot.

It is well-known that soil temperature and moisture are two very important soil microclimate variables that influence Rs (Lloyd and Taylor 1994; Tang et al. 2005b; Inclán et al. 2010), and soil heterotrophic respiration especially responded well to climate soil conditions (Zhao et al. 2019). In our experiment, although both sites have a similar slope and aspect, the increased soil temperature reflected thinning intensity: thinning did not affect the soil temperature at the HU site, but increased the soil temperature in the CA T plot by about 1.5 degrees vs. the CA C plot. Similar positive effects of thinning on soil temperature have been reported by other authors (Bolat 2014; Akburak and Makineci 2016). In relation to surface soil humidity, thinning treatment increases net rainfall by reducing interception losses by tree canopies (del Campo et al. 2018), but also increases direct evaporation from the exposed soil surface. The overall thinning effect at both sites favoured a reduction in surface soil humidity in summer under high evaporative demand conditions. Recently, Zhao et al. (2019) reported how autotrophic and heterotrophic respirations respond to thinning intensity independently of one another, and how heterotrophic respiration was more responsive to soil humidity. Soil heterotrophic activity concentrates in a shallow layer, where water content quickly changes, which explains the response of heterotrophic respiration to water content. Autotrophic soil respiration depends on water root uptake from deeper layers (Chang et al. 2016; Puertes et al. 2019), which is why it is less sensitive to surface soil water content variations. The effect of humidity on the Rs rate may be attributed to heterotrophic microbial respiration, which is very sensitive to surface soil humidity. In water-limited ecosystems, drought controls Rs.

The effect of forest thinning on soil respiration is the combined result of reduced plant density, increased soil organic matter and changing soil temperature and water content due to both thinning and local climate conditions (Tang et al. 2005a). In the model proposed by Tang et al. (2005b), surface soil temperature and humidity explained a high percentage of Rs variability. In our study, the optimal model with all the statistically significant terms at $p<0.05$ accounted for more than $40 \%$ of Rs variability in an Aleppo pine forest and a holm oak forest, with climate variables explaining a high percentage of Rs variability. Soil temperature showed an exponential relation to Rs with adjusted $\mathrm{Q}_{10}$ values ranging from 1.87 to 2.64 , and greater temperature sensitivity in the $\mathrm{HU}$ plots, where $\mathrm{Q}_{10}$ was affected by silvicultural treatment. The calculated $\mathrm{Q}_{10}$ values agree with the values often reported in the literature (Ohashi and Gyokusen 2007; Inclán et al. 2010). Pang et al. (2013) also found that thinning altered $\mathrm{Q}_{10}$. As $\mathrm{Q}_{10}$ reflects the increased velocity of a reaction with a $10^{\circ} \mathrm{C}$ increase in temperature, its value is determined not only by the speed of biochemical reactions, but also by increased microbial biomass. High $\mathrm{Q}_{10}$ values indicate full substrate availability when biomass increases (Davidson and Janssens 2006; Zhou et al. 2013). The effect of surface soil humidity on Rs was well-represented by a second-order polynomial model with microbial activity limited at a low soil humidity level, but also at a high humidity level due to oxygen deficiency. 
Several studies have revealed that litter heterotrophic respiration can be a primary source of $\mathrm{C}$ loss from forest ecosystems (Xiao et al. 2014; McElligott et al. 2017). Several others have compared the heterotrophic and autotrophic components of Rs. In a mixed oak ecosystem, Rey et al. (2003) report a distribution of $54.9 \%$ Rs produced by soil organic matter decomposition on an annual basis, $21.9 \%$ from aboveground litter decomposition and $23.3 \%$ from rhizosphere respiration. We observed that the mean Rs values in the control plots were higher in the pine forest than in the oak forest. Fernández-Alonso et al. (2018), who worked with two similar forests, also obtained higher Rs values in a Scots pine forest than in a Pyrenean oak forest because of higher heterotrophic respiration values in pine forests. They also indicated that soil heterotrophic respiration was the most important component, which accounted for $76 \%$ for Pyrenean oak and $88 \%$ for Scots pine of Rs. Their study measured heterotrophic Rs in soil with a soil organic matter content that was approximately threefold higher in pine forests than in oak forests. At the CA site in our experiment, the organic horizon was composed of a shallow litter layer, whose main component was partially decomposed needles with a high $\mathrm{C} / \mathrm{N}$ ratio, while mineral soil had a lower soil organic carbon content than the soil from HU. Thinning reduces soil autotrophic respiration, but temporary increase in litter respiration after thinning has been reported (Lagomarsino et al. 2020). As soil heterotrophic respiration relies on substrate availability, its value depends not only on the actual forest composition, but on the entire cumulative carbon balance throughout the soil's history.

\section{Conclusions}

Understanding the mechanisms that drive carbon loss from the soil surface is essential for ascertaining the impact of forest management on soil carbon sequestration. This work presents the complexity of the mechanisms that affect Rs spatial variability in Mediterranean mountain forest ecosystems.

The impact of forest thinning on the soil carbon balance depends on direct effects, such as reduced plant biomass and root respiration, increased plant residue and, hence, heterotrophic substrate respiration. Forest thinning also affects Rs, mainly due to indirect effects, e.g. changes in soil microclimate conditions, which leads to a higher soil organic matter decomposition rate. As Mediterranean climates are characterised by wide interannual variability, Rs shows considerable variability among years, which can mask the effect caused by thinning treatment.

The analysis of spatio-temporal variability helped us to understand the effect of adaptive forest management on Rs. Further work needs to consider the relation between Rs and the many factors that influence substrate availability, species distribution and microclimate variables on abrupt slopes.

Acknowledgements This study was supported by research projects Hydrological characterisation of forest structures on a plot scale for adaptive management (CGL2011-28776-C02-02) and SILWAMED (CGL2014-58127-C3-2) funded by the Spanish Ministry of Science and Innovation and FEDER funds. CEHYRFO-MED (CGL201786839-C3-2-R), RESILIENT-FORESTS (LIFE17 CCA/ES/000063) and SilvAdapt.net (RED2018-102719-T) are also acknowledged. The authors are grateful to the Valencia Regional Government, VAERSA, ACCIONA and the "Sierra Calderona" Natural Park for their support in allowing us to use experimental forests and for their assistance in fieldwork. We also thank Rafael Herrera from the Centro de Ecología, Instituto Venezolano de Investigaciones Científicas, Caracas, Venezuela, and the anonymous reviewers for critically reviewing the manuscript.

Funding Open Access funding provided thanks to the CRUE-Universitat Politècnica de València agreement with Springer Nature.

Open Access This article is licensed under a Creative Commons Attribution 4.0 International License, which permits use, sharing, adaptation, distribution and reproduction in any medium or format, as long as you give appropriate credit to the original author(s) and the source, provide a link to the Creative Commons licence, and indicate if changes were made. The images or other third party material in this article are included in the article's Creative Commons licence, unless indicated otherwise in a credit line to the material. If material is not included in the article's Creative Commons licence and your intended use is not permitted by statutory regulation or exceeds the permitted use, you will need to obtain permission directly from the copyright holder. To view a copy of this licence, visit http://creativecommons.org/licenses/by/4.0/.

\section{References}

Ágren GI, Knecht M (2001) Simulation of soil carbon and nutrient development under Pinus Sylvestris and Pinus contorta. Forest Ecol Manag 141:117-129. https://doi.org/10.1016/S03781127(00)00495-3

Akburak S, Makineci E. (2016). Thinning effects on soil and microbial respiration in a coppice-originated Carpinus betulus L. stand in Turkey. Iforest. 9 783. https://doi.org/10.3832/ifor1810-009

Almagro M, López J, Querejeta JI, Martínez-Mena M (2009) Temperature dependence of soil $\mathrm{CO}_{2}$ efflux is strongly modulated by seasonal patterns of moisture availability in a Mediterranean ecosystem. Soil Biol Biochem 41:594-605. https://doi.org/10.1016/j. soilbio.2008.12.021

Arias-Navarro C, Díaz-Pinés E, Klatt S, Brandt P, Rufino MC, Butterbach-Bahl K, Verchot LV (2017) Spatial variability of soil $\mathrm{N}_{2} \mathrm{O}$ and $\mathrm{CO}_{2}$ fluxes in different topographic positions in a tropical montane forest in Kenia. J Geophys Res Biogeosci 122:514-527. https://doi.org/10.1002/2016JG003667

Bautista I, Pabón CA, Lull C, González-Sanchis MC, Lidón A, del Campo AD (2015) Efectos de la gestión forestal en los flujos de nutrientes asociados al ciclo hidrológico en un bosque mediterráneo de Quercus ilex. Cuad Soc Esp Cienc for 41:343-354. https:// doi.org/10.31167/csef.v0i41.17400

Boerner REJ (1983) Nutrient dynamics of vegetation and detritus following two intesities of fire in the New Jersey pine barrens. Oecologia 59:129-134 
Bolat I (2014) The effect of thinning on microbial biomass C, N and basal respiration in black pine forest soils in Mudurnu, Turkey. Eur J for Res 133:131-139. https://doi.org/10.1007/ s10342-013-0752-8

Cabon A, Mouillot F, Lempereur M, Ourcival JM, Simioni G, Limousin JM (2018) Thinning increases tree growth by delaying drought-induced growth cessation in a Mediterranean evergreen oak coppice. Forest Ecol Manag 409:333-342. https://doi.org/10. 1016/j.foreco.2017.11.030

Campbell J, Alberti G, Martin J, Law BE (2009) Carbon dynamics of a ponderosa pine plantation following a thinning treatment in the northern Sierra Nevada. Forest Ecol Manag 257:453-463. https:// doi.org/10.1016/j.foreco.2008.09.021

Chang CT, Sperlich D, Sabaté S, Sánchez-Costa E, Cotillas M, Espelta JM, Gracia C (2016) Mitigating the stress of drought on soil respiration by selective thinning: Contrasting effects of drought on soil respiration of two oak species in a Mediterranean forest. Forests 7:263. https://doi.org/10.3390/f7110263

Cheng X, Kang F, Han H, Liu H, Zhang Y (2015) Effect of thinning on partitioned soil respiration in a young Pinus tabulaeformis plantation during growing season. Agric for Meteorol 214-215:473482. https://doi.org/10.1016/j.agrformet.2015.09.016

Curtin D, Beare MH, Hernandez-Ramirez G (2012) Temperature and humidity effects on microbial biomass and soil organic matter mineralization. Soil Sci Soc Am J 76:2055-2067. https://doi.org/ 10.2136/sssaj2012.0011

D'Amato AW, Bradford JB, Fraver S, Palik BJ (2013) Effects of thinning on drought vulnerability and climate response in north temperate forest ecosystems. Ecol Appl 23:1735-1742. https://doi. org/10.1890/13-0677.1

Davidson EA, Janssens IA (2006) Temperature sensitivity of soil carbon decomposition and feedbacks to climate change. Nature 440:165-173. https://doi.org/10.1038/nature04514

Davidson EA, Richardson AD, Savage KE, Hollinger DY (2006) A distinct seasonal pattern of the ratio of soil respiration to total ecosystem respiration in a spruce-dominated forest. Global Change Biol 12:230-239. https://doi.org/10.1111/j.1365-2486.2005.01062.x

del Campo AD, González-Sanchis M, Lidón A, García-Prats A, Lull C, Bautista I, Ruíz-Pérez G, Francés F (2017) Ecohydrologicalbased forest management in semi-arid climate. In: Krecek J, Haigh M, Hofer T, Kubin E, Promper C (eds) Ecosystem Services of Headwater Catchments. Springer. 45-57. https://doi.org/10.1007/ 978-3-319-57946-7_6

del Campo AD, González-Sanchis M, Lidón A, Ceacero C, GarcíaPrats A (2018) Rainfall partitioning in two low-biomass semiarid forest: impact of climate and forest structure on the effectiveness of water oriented treatments. J Hydrol 565:74-86. https://doi.org/ 10.1016/j.jhydrol.2018.08.013

del Campo AD, González-Sanchis M, Garcia-Prats A, Ceacero CJ, Lull C (2019) The impact of adaptive forest management on water fluxes and growth dynamics in a water-limited low-biomass oak coppice. Agric for Meteorol 264:266-282. https://doi.org/10. 1016/j.agrformet.2018.10.016

Dixon RK, Solomon AM, Brown S, Houghton RA, Trexier MC, Wisniewski J (1994) Carbon pools and flux of global forest ecosystems. Science 263:185-190. https://doi.org/10.1126/science.263. 5144.185

Ducrey M, Turrel M (1992) Influence of cutting methods and dates on stump sprouting in Holm oak (Quercus ilex L) coppice. Ann for Sci 49:449-464. https://doi.org/10.1051/forest:19920502

Fang Y, Gundersen P, Zhang W, Zhou G, Christiansen JR, Mo J, Dong S, Zhang T (2009) Soil-atmosphere exchange of $\mathrm{N}_{2} \mathrm{O}$, $\mathrm{CO}_{2}$ and $\mathrm{CH}_{4}$ along a slope of an evergreen broad-leaved forest in southern China. Plant Soil 319:37-48. https://doi.org/10.1007/ s11104-008-9847-2
Fernández-Alonso MJ, Diaz-Pines E, Ortiz C, Rubio A (2018) Disentangling the effects of tree species and microclimate on heterotrophic and autotrophic soil respiration in a Mediterranean ecotone forest. Forest Ecol Manag 430:533-544. https://doi.org/ 10.1016/j.foreco.2018.08.046

Goldin SR, Hutchinson MF (2013) Coarse woody debris modifies surface soils of degraded temperate eucalypt woodlands. Plant Soil 370:461-469. https://doi.org/10.1007/s11104-013-1642-z

Hanson PJ, Edwards NT, Gaeten CT, Andrews JA (2000) Separating root and soil microbial contributions to soil respiration: and review of methods and observations. Biogeochemistry 48:115146. https://doi.org/10.1023/A:1006244819642

Högberg P, Nordgren A, Buchmann N, Taylor AFS, Ekblad A, Högberg MN, Nyberg G, Ottosson-Löfvenius M, Read DJ (2001) Largescale forest girdling shows that current photosynthesis drives soil respiration. Nature 411:789-792. https://doi.org/10.1038/35081 058

Inclán R, Uribe C, De La Torre D, Sánchez DM, Clavero MA, Fernández AM, Morante R, Cardeña A, Fernández M, Rubio A (2010) Carbon dioxide fluxes across the Sierra de Guadarrama, Spain. Eur J for Res 129:93-100. https://doi.org/10.1007/ s10342-008-0247-1

Jandl R, Lindner M, Vesterdal L, Bauwens B, Baritz R, Hagedorn F, Johnson DW, Minkkinen K, Byrne KA (2007) How strongly can forest management influence soil carbon sequestration? Geoderma 137:253-268. https://doi.org/10.1016/j.geoderma.2006.09.003

Jandl R, Spathelf P, Bolte A, Prescott CE (2019) Forest adaptation to climate change-is non-management an option? Ann for Sci 76:48. https://doi.org/10.1007/s13595-019-0827-x

Lado-Monserrat L, Lull C, Bautista I, Lidón A, Herrera R (2014) Soil humidity increment as a controlling variable of the "Birch effect". Interactions with the pre-wetting soil humidity and litter addition. Plant Soil 379:21-34. https://doi.org/10.1007/s11104-014-2037-5

Lagomarsino A, Mazza G, Agnelli AE, Lorenzetti R, Bartoli C, Viti C, Colombo C, Pastorelli R (2020) Litter fractions and dynamics in a degraded pine forest after thinning treatments. Eur J Forest Res 139:295-310. https://doi.org/10.1007/s10342-019-01245-8

Lal R, Smith P, Jungkunst HF, Mitsch WJ, Lehmann J, Nair KPR, McBratney AB, de Moraes Sá JC, Schneider J, Zinn YL, Skorupa ALA, Zhang H, Minasny B, Srinivasrao C, Ravindranath NH (2018) The carbon sequestration potential of terrestrial ecosystems. J Soil Water Conserv 73:145A-152A. https://doi.org/10. 2489/jswc.73.6.145A

Lindner M, Maroschek M, Netherer S, Kremer A, Barbati A, GarciaGonzalo J, Seidl R, Delzon S, Corona P, Kolström M, Lexer MJ, Marchetti M (2010) Climate change impacts, adaptive capacity, and vulnerability of European forest ecosystems Forest Ecol Manag 259: 698-709. https://doi.org/10.1016/j.foreco.2009.09. 023

Lloyd J, Taylor JA (1994) On the temperature dependence of soil respiration. Funct Ecol 8:315-323. https://doi.org/10.2307/2389824

López BC, Sabaté S, Gracia CA (2003) Thinning effects on carbon allocation to fine roots in a Quercus ilex forest. Tree Physiol 23:1217-1224. https://doi.org/10.1093/treephys/23.17.1217

López-Serrano FR, Rubio E, Dadi T, Moya D, Andrés-Abellán M, García-Morote FA, Martínez-García E (2016) Influences of recovery from wildfire and thinning on soil respiration of a Mediterranean mixed forest. Sci Total Environ 573:1217-1231. https:// doi.org/10.1016/j.scitotenv.2016.03.242

Lull C, Bautista I, Lidón A, del Campo AD, González-Sanchis M, García-Prats A (2020) Temporal effects of thinning on soil organic carbon pools, basal respiration and enzyme activities in a Mediterranean Holm oak forest. Forest Ecol Manage 464:118088. https:// doi.org/10.1016/j.foreco.2020.118088

Ma S, Chen J, North M, Erickson HE, Bresee M, Le Moine J (2004) Short-term effects of experimental burning and thinning on soil 
respiration in an old-growth, mixed-conifer forest. Environ Manag 33:148-159. https://doi.org/10.1007/s00267-003-9125-2

Mallik AU, Hu D (1997) Soil respiration following site preparation treatments in boreal mixedwood forest. For Ecol Manag 97:265275. https://doi.org/10.1016/S0378-1127(97)00067-4

MAPA (1994) Métodos oficiales de análisis de suelos y aguas. Ministerio de Agricultura, Pesca y Alimentación, Madrid

Martin JG, Bolstad PV (2009) Variation of soil respiration at three spatial scales: Components within measurements, intra-site variation and patterns on the lanscape. Soil Biol Biochem 41:530-543. https://doi.org/10.1016/j.soilbio.2008.12.012

Martin WKE, Timmer VR (2006) Capturing spatial variability of soil and litter properties in a forest stand by landform segmentation procedures. Geoderma 132:169-181. https://doi.org/10.1016/j. geoderma.2005.05.004

Martínez-García E, López-Serrano FR, Dadi T, García-Morote FA, Andrés-Abellán M, Pumpanen J, Rubio E (2017) Medium-term dynamics of soil respiration in a Mediterranean mountain ecosystem: The effects of burn severity, post-fire burnt-wood management, and slope-aspect. Agric for Meteorol 233:195-208. https://doi.org/10.1016/j.agrformet.2016.11.192

McElligott KM, Seiler JR, Strahm BD (2017) The impact of water content on sources of heterotrophic soil respiration. Forests 8:299. https://doi.org/10.3390/f8080299

Millar CI, Stephenson NL, Stephens SL (2007) Climate change and forests of the future: managing in the face of uncertainty. Ecol Appl 17:2145-2151. https://doi.org/10.1890/06-1715.1

Molina A, del Campo A (2012) The effects of experimental thinning on throughfall and stemflow: a contribution towards hydrology-oriented silviculture in Aleppo pine plantations. For Ecol Manag 269:206-213. https://doi.org/10.1016/j.foreco.2011.12. 037

Moyano FE, Vasilyeva NA, Bouckaert L, Cook F, Craine JM, Don A, Epron D, Formanek P, Franzluebbers A, Ilstedt U, Katterer T, Orchard V, Reichstein M, Rey A, Ruamps LS, Subke J, Thomsen IK, Chenu C (2012) The moisture response of soil heterotrophic respiration: Interaction with soil properties. Biogeosciences 9:1173-1182. https://doi.org/10.5194/bg-9-1173-2012

Nelson, DW, Sommers LE (1982) Total carbon, organic carbon and organic matter. In: Page AL, Miller RH, Jeeney DR (eds) Methods of soil analysis. Part 2. Chemical and mineralogical properties. American Society of Agronomy, Madison, 9. 539-579

Newman GS, Arthur MA, Muller RN (2006) Above-and belowground net primary production in a temperate mixed deciduous forest. Ecosystems 9:317-329. https://doi.org/10.1007/ s10021-006-0015-3

Ohashi M, Gyokusen K (2007) Temporal change in spatial variability of soil respiration on a slope of Japanese cedar (Cryptomeria japonica D. Don) forest. Soil Biol Biochem 39:1130-1138. https://doi.org/10.1016/j.soilbio.2006.12.021

Ohashi M, Gyokusen K, Saito A (1999) Measurement of carbon dioxide evolution from a Japanese cedar (Cryptomeria japonica D. Don) forest floor using an open-flow chamber method. For Ecol Manag 123:105-114. https://doi.org/10.1016/S03781127(99)00020-1

Olajuyigbe S, Tobin B, Saunders M, Nieuwenhuis M (2012) Forest thinning and soil respiration in a Sitka spruce forest in Ireland. Agric for Meteorol 157:86-95. https://doi.org/10.1016/j.agrfo rmet.2012.01.016

Olivar J, Bogino S, Rathgeber C, Bonnesoeur V, Bravo F (2014) Thinning has a positive effect on growth dynamics and growthclimate relationships in Aleppo pine (Pinus halepensis) trees of different crown classes. Ann for Sci 71:395-404. https://doi.org/ 10.1007/s13595-013-0348-y

Pang X, Bao W, Zhu B, Cheng W (2013) Responses of soil respiration and its temperature sensitivity to thinning in a pine plantation. Agric for Meteorol 171:57-64. https://doi.org/10. 1016/j.agrformet.2012.12.001

Peng Y, Thomas SC, Tian D (2008) Forest management and soil respiration: implications for carbon sequestration: Environ. Rev 16:93-111. https://doi.org/10.1139/A08-003

Pennock D, Yates T, Braidek J (2008) Soil sampling designs. In: Carter MR, Gregorich EG (eds) Soil sampling and methods of analysis, 2on edn. CRC Press, pp 1-14

Puertes C, Lidón A, Echeverría C, Bautista I, González-Sanchis M, del Campo AD, Francés F (2019) Explaining the hydrological behaviour of facultative phreatophytes using a multi-variable and multi-objective modelling approach. J Hydrol 575:395-407. https://doi.org/10.1016/j.jhydrol.2019.05.041

R Development Core Team (2017) R version 3.3.3. R Foundation for Statistical Computing.

Rey A, Pegoraro E, Tedeschi V, de Parri I, Jarvis PG, Valentini R (2003) Annual variation in soil respiration and its components in a coppice oak forest in Central Italy. Glob Change Biol 8:851-866. https://doi.org/10.1046/j.1365-2486.2002.00521.x

Scarascia-Mugnozza G, Oswald H, Piussi P, Radoglou K (2000) Forests of the Mediterranean region: gaps in knowledge and research needs. For Ecol Manag 132:97-109. https://doi.org/ 10.1016/S0378-1127(00)00383-2

Spears JDH, Lajtha K (2004) The imprint of coarse woody debris on soil chemistry in the western Oregon Cascades. Biogeochemistry 71:163-175. https://doi.org/10.1007/s10533-004-6395-6

Striegl RJ, Wickland KP (1998) Effects of a clear-cut harvest on soil respiration in a jack pine-lichen woodland. Can J for Res 28:534-539. https://doi.org/10.1139/x98-023

Tang J, Misson L, Gerhenson A, Cheng W, Goldstein AH (2005a) Continuous measurements of soil respiration with and without roots in a ponderosa pine plantation in the Sierra Nevada Mountains. Agric for Meteorol 132:212-227. https://doi.org/10. 1016/j.agrformet.2005.07.011

Tang J, Qi Y, Xu M, Misson L, Goldstein AH (2005b) Forest thinning and soil respiration in a ponderosa pine plantation in the Sierra Nevada. Tree Physiol 25:57-66. https://doi.org/10.1093/ treephys/25.1.57

Thibodeau L, Raymond P, Camiré C, Munson AD (2000) Impact of precommercial thinning in balsam fir stands on soil nitrogen dynamics, microbial biomass, decomposition and foliar nutrition. Can J for Res 30:229-238. https://doi.org/10.1139/x99-202

Toland DE, Zak DR (1994) Seasonal patterns of soil respiration in intact and clear-cut northern hardwood forests. Can J for Res 24:1711-1716. https://doi.org/10.1139/x94-221

Ukonmaanaho L, Merilä P, Nöjd P, Nieminen TM (2008) Litterfall production and nutrient return to the forest floor in Scots pine and Norway spruce stands in Finland. Boreal Env Res 13: 67-91. http://urn.fi/URN:NBN:fi-fe2016091323703

UNEP (United Nations Environment Programme) (1992) World atlas of desertification. Edited by Middleton N, Thomas DSG, Arnold E, London. https://doi.org/10.1002/ldr.3400030407

Xiao W, Ge X, Zeng L, Huang Z, Lei J, Zhou B, Li M (2014) Rates of litter decomposition and soil respiration in relation to soil temperature and water in different-aged Pinus massoniana forests in the three Gorges Reservoir area. China Plos ONE 9:e101890. https://doi.org/10.1371/journal.pone.0101890

$\mathrm{Xu}$ M, Qi Y (2001) Soil-surface $\mathrm{CO}_{2}$ efflux and its spatial and temporal variations in a young ponderosa pine plantation in northern California. Glob Change Biol 7:667-677. https://doi.org/10. 1046/j.1354-1013.2001.00435.x

Xu J, Chen J, Brosofske K, Li Q, Weintraub M, Henderson R, Wilske B, John R, Jensen R, Li H, Shao C (2011) Influence of timber harvesting alternatives on forest soil respiration and its biophysical regulatory factors over a 5-year period in the Missouri 
Ozarks. Ecosystems 14:1310-1327. https://doi.org/10.1007/ s10021-011-9482-2

Yaalon DH (1997) Soils in the Mediterranean region: what makes them different? CATENA 28:157-169. https://doi.org/10.1016/ S0341-8162(96)00035-5

Yakovchenko VP, Sikora LJ (1998) Modified dichromate method for determining low concentrations of extractable organic carbon in soil. Commun Soil Sci Plant Anal 29:421-433. https://doi.org/ 10.1080/00103629809369955

Zhang X, Guan D, Li W, Suna D, Jin C, Yuan F, Wang A, Wu J (2018) The effects of forest thinning on soil carbon stocks and dynamics: A meta-analysis. For Ecol Manag 429:36-43. https:// doi.org/10.1016/j.foreco.2018.06.027
Zhao B, Gao J, Geng Y, Zhao X, von Gadow K (2019) Inconsistent responses of soil respiration and its components to thinning intensity in a Pinus tabuliformis plantation in northern China. Agric for Meteorol 265:370-380. https://doi.org/10.1016/j.agrfo rmet.2018.11.034

Zhou Z, Guo C, Meng H (2013) Temperature sensitivity and basal rate of soil respiration and their determinants in temperate forests of north China. PLoS ONE 8:e81793. https://doi.org/10. 1371/journal.pone.0081793

Publisher's Note Springer Nature remains neutral with regard to jurisdictional claims in published maps and institutional affiliations. 